\title{
Antibiotic resistance of Aeromonas spp. isolated from diseased walking catfish (Clarias sp.)
}

\author{
DINI SISWANI MULIA ${ }^{1}$, ALIM ISNANSETYO ${ }^{2, \boldsymbol{v}}$, RARASTOETI PRATIWI $^{3}$, WIDYA ASMARA ${ }^{4}$ \\ ${ }^{1}$ Department of Biology Education, Faculty of Teacher Training and Education, Universitas Muhammadiyah Purwokerto. Jl. KH. Ahmad Dahlan, \\ Purwokerto Utara, Banyumas 53182, Central Java, Indonesia. \\ ${ }^{2}$ Department of Fisheries, Faculty of Agriculture, Universitas Gadjah Mada. Jl. Flora, Bulaksumur, Sleman 55281, Yogyakarta, Indonesia. \\ Tel.: +62-274-551218, `email: isnansetyo@ugm.ac.id \\ ${ }^{3}$ Faculty of Biology, Universitas Gadjah Mada. J1. Teknika Selatan, Senolowo, Sleman 55281, Yogyakarta, Indonesia \\ ${ }^{4}$ Faculty of Veterinary Medicine, Universitas Gadjah Mada. Jl. Fauna, Caturtunggal, Sleman 55281, Yogyakarta, Indonesia
}

Manuscript received: 29 August 2021. Revision accepted: 17 October 2021.

\begin{abstract}
Mulia DS, Isnansetyo A, Pratiwi R, Asmara W. 2021. Antibiotic resistance of Aeromonas spp. isolated from diseased walking catfish (Clarias sp.). Biodiversitas 22: 4839-4846. Aeromonas spp. is known to be pathogenic to freshwater fish, including catfish. Antibiotics are often used to overcome bacterial attacks. However, the indiscriminate use of antibiotics, especially at incorrect doses and frequencies, could result in the emergence of resistant bacteria. The presence of resistance genes is also suspected to trigger the resistance potential of Aeromonas sp. against antibiotics. The objective of this study is to characterize the resistance genes of Aeromonas spp. isolated from diseased walking catfish (Clarias sp.). Ten Aeromonas spp. were isolated from infected walking catfish cultivated in Java. The resistance genes assessed included tetA, strA-strB, and qnrA. The antibiotics tested consisted of ampicillin (AMP), erythromycin (ERY), oxytetracycline (OXT), kanamycin (KAN), enrofloxacin (ENRO), and chloramphenicol (CHL). Results showed that some Aeromonas spp. had at least one out of the three genes assessed (i.e., tetA and strA-strB) but none had the qnrA gene. Aeromonas spp. were sensitive to KAN, ENRO, and CHL but resistant to AMP, ERY, and OXT. Thus, KAN, ENRO, and CHL are effective antibiotics for treating fish infected with Aeromonas spp.
\end{abstract}

Keywords: Aeromonas, antibiotics, walking catfish, gene, resistance

\section{INTRODUCTION}

Several obstacles, especially disease, must be addressed for successful freshwater fish cultivation. The diseases cause high mortality rates in fish, which can result in crop failure and massive financial losses. This problem is prevalent even in walking catfish (Clarias sp.) cultivation. Motile Aeromonas septicemia disease or aeromoniasis is caused by Aeromonas spp. These pathogens are opportunistic, gram negative, rod-shaped, facultative anaerobic bacteria, oxidase-positive, motile or non-motile, and non-spore-forming (Erdem et al. 2011; Parker and Shaw 2011; Aravena-Román et al. 2013; Percival and Williams 2014; Martínez-Murcia et al. 2016; Stratev and Odeyemi 2016).

Aeromonas spp. can attack nearly all types of fish and aquatic biota. Previous studies reported that Aeromonas spp. attacks catfish (Clarias gariepinus), Nile tilapia (Oreochromis niloticus), Arapaima gigas, eel (Anguilla japonica), rainbow trout (Onchorynchus mykiss), shrimp (Litopenaeus vannamei, Penaeus monodon), Chinese giant salamander (Andrias davidianus), and turtle (Ocadia sinensis, Pseudemys peninsularis) (Wang et al. 2012; Vega-Sanchez et al. 2014; Yano et al. 2015; Dias et al 2016; Guo et al. 2016; Hassan et al. 2017; Wimalasena et al. 2017; Sellegounder et al. 2018; Eid et al. 2019). In Indonesia, the first Aeromonas spp. outbreak was recorded in West Java in 1980. Aeromonas spp. attack caused the death of 82.2 tons of fish within 1 month. Another attack was recorded in Central Java in 1984, in which approximately 1.6 tons of catfish died (Angka 2001). Since then, Aeromonas spp. infection in fish has become increasingly common. Besides its virulence potential, the ability of Aeromonas spp. to cause disease in fish may be attributed to its resistance to antibiotics; this resistance enables the bacteria to survive, become immune to antibiotics, and continue infecting fish and other aquatic biotas. Aeromonas spp. are well known for their resistance genes and natural defense system. Despite the potential dangers of Aeromonas spp. infection, there is a lack of research concerning this important pathogen in Indonesia . Research abroad has successfully detected various resistance genes in Aeromonas spp., including tetE, tetO, tetA, bla ${ }_{\mathrm{TEM}}$, strA-strB, qnrS2, and qnrA (Nawaz et al. 2012; Deng et al. 2014; Varela et al. 2016; Harnisz and Korzeniewska 2018; De Silva et al. 2020). Knowledge of the resistance genes of this bacterium is essential to determine the most suitable antibiotics for controlling Aeromonas spp. infection.

Several antibiotics, including chlortetracycline, oxytetracycline (OXT), tetracycline, erythromycin (ERY), and enrofloxacin (ENRO) (Kepmen-KP 2014), as well as ampicillin (AMP), kanamycin (KAN), and chloramphenicol (CHL), are often used to control virulent bacteria. However, the inappropriate use of antibiotics, especially in terms of time, dose, and target, is common. 
This practice may potentially lead to bacterial resistance (Parker and Shaw 2011). Research on antibiotics is also necessary to identify effective drugs against specific pathogens. The resistance of Aeromonas spp. to various antimicrobials is feature that must be comprehensively studied. Thus, the aim of the present study is to characterize the resistance of Aeromonas spp. isolated from walking catfish (Clarias sp.).

\section{MATERIALS AND METHODS}

\section{Bacterial isolates of Aeromonas spp.}

Bacterial strains of Aeromonas spp. were obtained from the kidneys of infected walking catfish cultivated ponds in Yogyakarta, Central Java, and West Java, Indonesia.

\section{Detection of resistance genes in Aeromonas spp.}

The resistance genes investigated in this work included tetA, strA-strB, and qnrA. Polymerase chain reaction (PCR) was conducted using tubes with a capacity of 200 $\mu \mathrm{L}$. Each $25 \mu \mathrm{L}$ reaction mixture consisted of $12 \mu \mathrm{L}$ of $2 \times$ PCR Master Mix (Mytaq HS Red Mix, Bioline), $1 \mu \mathrm{L}$ each of the forward and reverse primers, $1 \mu \mathrm{L}$ of the DNA template $(20 \mathrm{ng}$ ), and $10 \mu \mathrm{L}$ of NFW (Mulia et al. 2020). The PCR products were electrophoresed with $1.5 \%$ gel agarose gel running with tris acetate EDTA (TAE) buffer.

\section{Resistance test of Aeromonas spp. by minimum inhibitor concentration (MIC) of antibiotics}

Aeromonas spp. resistance tests were conducted on bacterial isolates according to the MICs of the selected antibiotics, via the microdilution method (NCCLS 1994). Six antibiotics, namely oxytetracycline (OXT), kanamycin (KAN), ampicillin (AMP), enrofloxacin (ENRO), erythromycin (ERY), chloramphenicol (CHL) was used for resistance test. MIC test was performed in triplicates. The antibiotics tested included AMP, KAN (Wako Pure Chemical Industries, Osaka, Japan), OXT, ENRO, ERY, and CHL (Sigma Corporate, St. Louis, MI, USA). Bacterial isolates were inoculated on Mueller-Hilton broth. Antimicrobial susceptibility assay was performed in plates with flatbottomed wells and then plates were incubated at $30^{\circ} \mathrm{C}$ for $24 \mathrm{~h}$. After incubation, $10 \mu \mathrm{L}$ of resazurin was added to all wells of the microplate. Another cycle of incubation was performed at $30^{\circ} \mathrm{C}$, and observation was conducted $1 \mathrm{~h}$ later.

\section{Resistance development test of Aeromonas spp. by} minimum bactericidal concentration (MBC) of antibiotics

MBCs were determined from the obtained MICs, and the effects of MBCs of MIC, $2 \times \mathrm{MIC}, 4 \times \mathrm{MIC}$, and $6 \times \mathrm{MIC}$ (Isnansetyo and Kamei 2009) were also determined. The MBC test was conducted using the microdilution method (NCCLS 1994). After $24 \mathrm{~h}$ of incubation at $30^{\circ} \mathrm{C}$, bacteria treated with the selected concentrations of antibiotics, including control, were grown on glutamate starch phenyl (GSP) medium by using the streak method. Each experiment was performed in triplicate. Samples grown in GSP medium were then incubated at $30^{\circ} \mathrm{C}$ for $48 \mathrm{~h}$. Colonies appeared on the streaked line in GSP medium indicating bacterial growth. Bactericidal effects were identified when bacteria from the wells containing antibiotics failed to grow after $48 \mathrm{~h}$ of incubation.

\section{Data analysis}

Data from the detection of resistance genes, resistance tests of Aeromonas spp. based on MICs, and resistance development tests based on MBCs were analyzed descriptively. The primers of the resistance genes (i.e., tetA, strA-strB, and qnrA) were used according to Mulia et al. (2020).

\section{RESULTS AND DISCUSSION}

\section{Isolates of Aeromonas spp.}

Ten isolates of Aeromonas spp., including four $A$. dhakensis isolates (SB-01, MS-03, KK-02, and KO-01), four $A$. veronii bv. veronii isolates (SC-03, DW-04, BCp02-1, and $\mathrm{BCp}-02-2$ ), one A. caviae isolate (MD-03), and one $A$. hydrophila isolate (BCp-01-2) were assessed in this study (Table 1).

\section{Detection of resistance genes of Aeromonas spp.}

The result showed that tetA gene was detected in three isolates, namely, A. dhakensis MS-03, A. hydrophila BCp01-2, and $A$. veronii bv. veronii $\mathrm{BCp}-02-2$ (Figure 1a). The $s t r A-s t r B$ gene was found in three isolates, namely, $A$. veronii bv. veronii SC-03, A. dhakensis KK02, and $A$. caviae MD-03 (Figure 1b). The qnrA gene was not detected in any of the isolates.

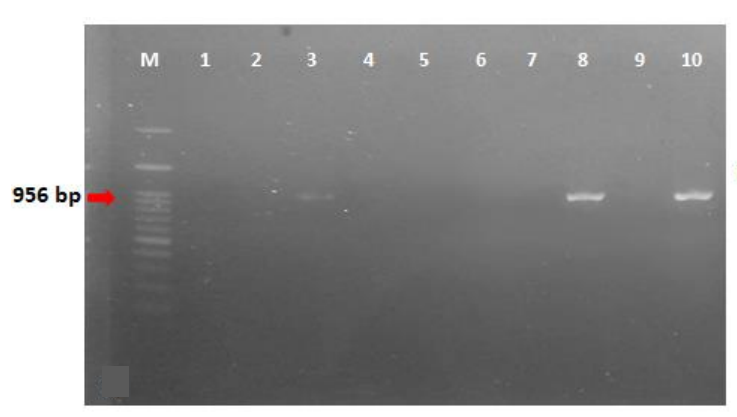

A

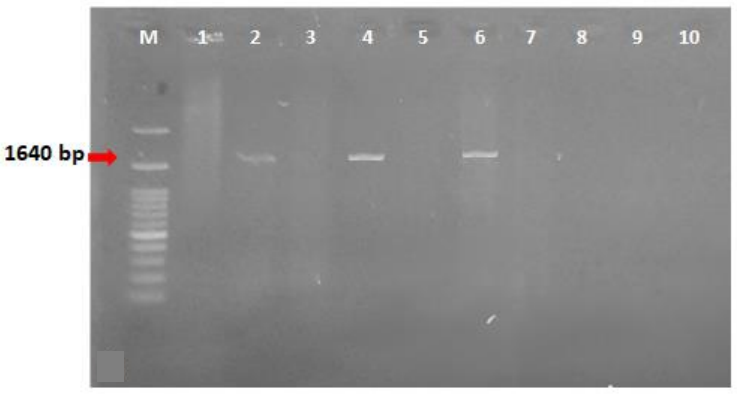

B

Figure 1. Amplification of resistance genes in Aeromonas spp. (a) tetA gene, 956 bp; M, DNA Marker 100 bp; Lane 1, SB-01; 2, SC-03; 3, MS-03; 4, KK-02; 5, KO-01; 6, MD-03; 7, DW-04; 8, BCp-01-2; 9, BCp-02-1; 10, BCp-02-2. (b) strA-strB gene, 1640 bp. 
Table 1 shows that tet $A$ genes was found in $A$. dhakensis $\mathrm{MS}-03$, A. hydrophila $\mathrm{BCp}-01-2$, and $A$. veronii bv. veronii $\mathrm{BCp}-02-2$ isolates ( $30 \%$ isolates); strA-strB genes was found in $A$. veronii bv. veronii $\mathrm{SC}-03, A$. dhakensis $\mathrm{KK} 02$, and A. caviae MD-03 isolates (30\% isolates), and $q n r A$ gene were not found in any isolate. The $q n r A$ gene, as in previous studies, was not detected in any of the isolates tested (Varela et al. 2016; Wimalasena et al. 2017).

Six isolates showed one resistance gene, whereas four isolates did not show a single resistance genes. Two $A$. dhakensis isolates, i.e. MS-03 and KK-02, had tetA and strA-strB resistance genes, respectively. However, two other A. dhakensis isolates, i.e. SB-01 and KO-01, had no resistance genes. One $A$. veronii bv. veronii isolate, i.e. BCp-02-2, had tetA gene, while SC-03 had strA-strB gene. No resistance genes were detected in DW-04 and BCp-021. Previous research results reported that the tetA gene is found in $A$. veronii isolated from fish and turtles (Deng et al. 2014). The strA-strB gene was detected in A. caviae MD-03 but tetA gene was not. These results differ from previous studies, which reported the detection of tetA gene, but not strA or strB genes in A. caviae isolated from shrimp and catfish (Deng et al. 2014; Mulia et al. 2020).

A. hydrophila $\mathrm{BCp}-01-1$ was detected to have tetA gene but not $\operatorname{str} A-s t r B$ gene. The same finding was reported by Deng et al. (2014), who detected tetA gene but not strAstrB gene in $A$. hydrophila isolated from fish. Other studies have successfully detected tetA gene from A. hydrophila isolated from shrimp and farm-raised fish (De Silva et al. 2018). However, different results were obtained by Tipmongkolsilp et al. (2012), who did not find tetA gene in A. hydrophila.

The results revealed that only tetA and strA-strB genes were found in the selected isolates, but these genes were not always present in every isolate. However, the presence or absence of tetA and strA-strB genes in isolates did not always translate to consistent resistance to the tested antibiotics. In fact, the presence of a resistance gene in a bacterium indicates some protection against the effects of antibiotics. The tetA gene encodes proteins that protect ribosomes and suppress tetracycline. These genes are often associated with plasmids, transposons, and integrons as conjugative and mobilization elements in bacteria. Most of the tet genes encode transport proteins. The proteins are responsible for pumping antibiotics out of bacterial cells and maintaining low intercellular antibiotic concentrations to allow the normal function of ribosomes (Nguyen et al. 2014).

The strA-strB gene is an aminoglycoside-resistant gene. Aminocyclitol is an aminoglycoside that inhibits protein synthesis to kill bacteria. This antibiotic group binds to the 16S rRNA gene and disrupts the integrity of the bacterial cell membrane (Shakil et al. 2008).

Previous studies have observed inconsistency between the occupation of resistance genes and resistance to antibiotics and vice versa. Out of 12 isolates of Aeromonas spp. that were resistant to the aminoglycoside group, only one was detected to have strA-strB gene (De Silva et al. 2020). In addition, Aeromonas spp. isolated from fish and shrimp did not have amplicons for strA-strB gene, but some isolates were resistant to the aminoglycoside group (Deng et al. 2014). The results of this study indicate that the presence of resistance genes varies among species and that the presence of these genes is not always synonymous with the ability to resist antibiotics (Dahanayake et al. 2019). Increasing the understanding of the diversity distribution of bacteria resistant to antibiotics is essential to prevent these bacteria from spreading (Stoll et al. 2012). The presence of a resistance gene does not consistently mean resistance to antibiotics and vice versa (Dahanayake et al. 2019).

Table 1. Aeromonas spp. with resistance genes

\begin{tabular}{|c|c|c|c|c|c|c|}
\hline \multirow[t]{2}{*}{ Isolates } & \multirow[t]{2}{*}{ Origin of isolates } & \multirow[t]{2}{*}{ Species } & \multicolumn{3}{|c|}{$\begin{array}{c}\text { Resistance genes detected in } \\
\text { Aeromonas spp. }\end{array}$} & \multirow[t]{2}{*}{ Total $(\%)$} \\
\hline & & & tetA & strA-strB & qnrA & \\
\hline$\overline{\text { SB-01 }}$ & Sleman (DIY) & A. dhakensis strain $\mathrm{P} 21$ & - & - & - & $0(0 \%)$ \\
\hline SC-03 & Sleman (DIY) & A. veronii bv. veronii strain ATCC 35624 & - & + & - & $1(33.33 \%)$ \\
\hline MS-03 & Magelang (Central Java) & A. dhakensis strain $\mathrm{P} 21$ & + & - & - & $1(33.33 \%)$ \\
\hline KK-02 & Kulonprogo (DIY) & A. dhakensis strain $\mathrm{P} 21$ & - & + & - & $1(33.33 \%)$ \\
\hline KO-01 & Kedung Ombo (Central Java) & A. dhakensis strain $\mathrm{P} 21$ & - & - & - & $0(0 \%)$ \\
\hline MD-03 & Magelang (Central Java) & A. caviae strain ATCC 15468 & - & + & - & $1(33.33 \%)$ \\
\hline DW-04 & Demak (Central Java) & A. veronii bv. veronii strain ATCC 35624 & - & - & - & $0(0 \%)$ \\
\hline BCp-01-2 & Bogor (West Java) & A. hydrophila strain ATCC 7966 & + & - & - & $1(33.33 \%)$ \\
\hline BCp-02-1 & Bogor (West Java) & A. veronii bv. veronii strain ATCC 35624 & - & - & - & $0(0 \%)$ \\
\hline BCp-02-2 & Bogor (West Java) & A. veronii bv. veronii strain ATCC 35624 & + & - & - & $1(33.33 \%)$ \\
\hline Total $(\%)$ & & & $3(30 \%)$ & $3(30 \%)$ & $0(0 \%)$ & 6 \\
\hline
\end{tabular}




\section{Resistance test of Aeromonas spp. based on the MICs of antibiotics}

The resistance of Aeromonas spp. was determined via the microplate microdilution method on the basis of the MICs of the antibiotics. Bacteria that grew in wells with the highest concentration of antibiotics $(10 \mu \mathrm{g} / \mathrm{mL})$ were considered resistant to these antibiotics. Ambadiang et al. (2020) revealed that $\mathrm{MIC} \leq 10 \mu \mathrm{g} / \mathrm{mL}$ indicates strong activity. Thus, no inhibitory test with antibiotic concentrations above $10 \mu \mathrm{g} / \mathrm{mL}$ was conducted because it is no longer effective. The results showed that $A$. dhakensis isolates SB-01, MS-03, KK-02, and KO-01 were resistant and sensitive to various levels of antibiotics (Table 2). Isolate SB-01 was resistant to ERY, but sensitive to OXT and $\operatorname{AMP}(10 \mu \mathrm{g} / \mathrm{mL}), \mathrm{KAN}$ and $\mathrm{CHL}(5 \mu \mathrm{g} / \mathrm{mL})$, and ENRO $(0.2 \mu \mathrm{g} / \mathrm{mL})$. Isolate MS-03 was resistant to KAN, AMP, and ERY, but sensitive to CHL $(7.5 \mu \mathrm{g} / \mathrm{mL})$, OXT $(2.5 \mu \mathrm{g} / \mathrm{mL})$, and $\operatorname{ENRO}(1.875 \mu \mathrm{g} / \mathrm{mL})$. Isolate $\mathrm{KK}-02$ was unaffected by OXT and AMP, but sensitive to KAN (7.5 $\mu \mathrm{g} / \mathrm{mL})$, ERY $(3.75 \mu \mathrm{g} / \mathrm{mL})$, CHL $(2.5 \mu \mathrm{g} / \mathrm{mL})$, and ENRO $(0.1 \mu \mathrm{g} / \mathrm{mL})$. Isolate $\mathrm{KO}-01$ was unaffected by AMP, ERY, and CHL, but sensitive to KAN $(2.5 \mu \mathrm{g} / \mathrm{mL})$, OXT $(1.25 \mu \mathrm{g} / \mathrm{mL})$, and ENRO $(0.313 \mu \mathrm{g} / \mathrm{mL})$.

Aeromonas veronii bv. veronii $\mathrm{SC}-03$, DW-04, BCp-021 , and $\mathrm{BCp}-02-2$ were resistant and sensitive to different levels of antibiotics. Isolate SC-03 was insensitive to OXT, AMP, ERY, and CHL, but sensitive to KAN $(2.5 \mu \mathrm{g} / \mathrm{mL})$ and ENRO $(0.05 \mu \mathrm{g} / \mathrm{mL})$. Isolate DW-04 was resistant to ERY, but sensitive to OXT $(10 \mu \mathrm{g} / \mathrm{mL}), \mathrm{CHL}(1.875$ $\mu \mathrm{g} / \mathrm{mL}), \mathrm{KAN}$ and ENRO $(0.625 \mu \mathrm{g} / \mathrm{mL})$, and AMP $(0.2$ $\mu \mathrm{g} / \mathrm{mL})$. Isolate $\mathrm{BCp}-02-1$ was resistant to AMP, but sensitive to OXT and $\mathrm{KAN}(5 \mu \mathrm{g} / \mathrm{mL})$, ERY $(0.625$ $\mu \mathrm{g} / \mathrm{mL}), \mathrm{CHL}(0.313 \mu \mathrm{g} / \mathrm{mL})$, and ENRO $(0.025 \mu \mathrm{g} / \mathrm{mL})$. Isolate BCp-02-2 was resistant to OXT and AMP, but sensitive to ERY $(3.75 \mu \mathrm{g} / \mathrm{mL}), \mathrm{KAN}(2.5 \mu \mathrm{g} / \mathrm{mL}), \mathrm{CHL}$ $(1.25 \mu \mathrm{g} / \mathrm{mL})$, and ENRO $(0.2 \mu \mathrm{g} / \mathrm{mL})$. A. caviae MD-03 was unaffected by OXT, AMP, ERY, and CHL, but sensitive to KAN $(2.5 \mu \mathrm{g} / \mathrm{mL})$ and $\operatorname{ENRO}(0.05 \mu \mathrm{g} / \mathrm{mL})$. $A$. hydrophila $\mathrm{BCp}-01-2$ was resistant to AMP and ERY, but sensitive to OXT $(10 \mu \mathrm{g} / \mathrm{mL}), \mathrm{KAN}(6.25 \mu \mathrm{g} / \mathrm{mL}), \mathrm{CHL}$ $(1.875 \mu \mathrm{g} / \mathrm{mL})$, and $\operatorname{ENRO}(0.013 \mu \mathrm{g} / \mathrm{mL})$.

The resistance of Aeromonas spp. against the tested antibiotics tended to vary. However, previous reports revealed increased bacterial resistance against most commonly used antibiotics. The results showed variations in resistance among each of the A. dhakensis and A. veronii bv. veronii isolates. Most of the isolates were resistant to AMP, ERY, and OXT, some isolates were resistant to KAN and CHL. All the isolates showed sensitivity to ENRO in the resistance test.

A. dhakensis SB-01 and KO-01, as well as $A$. veronii bv. veronii DW-04 and BCp-02-1, did not have tet $A$ and strA-strB genes and were found to be sensitive to OXT and KAN. A. dhakensis MS-03, A. hydrophila $\mathrm{BCp}-01-2$, and A. veronii bv. veronii $\mathrm{BCp}-02-2$ had only tetA gene. A. veronii bv. veronii $\mathrm{BCp}-02-2$ was resistant to $\mathrm{OXT}$, but the other two isolates were actually sensitive to OXT. The absence of strA-strB gene rendered A. hydrophila BCp-01-
2 and $A$. veronii bv. veronii $\mathrm{BCp}-02-2$ sensitive to $\mathrm{KAN}$, but $A$. dhakensis MS-03 was resistant to this antibiotic. A. veronii bv. veronii $\mathrm{SC}-03$ and $A$. dhakensis $\mathrm{KK}-02$ had strA-strB genes and were resistant to OXT and sensitive to KAN. A. caviae MD-03 had only strA-strB gene and was resistant to OXT but sensitive to KAN. A. hydrophila BCp01-2 had only tetA gene and found sensitive to KAN and OXT. Some isolates were not detected to have tetA gene, but were resistant to OXT, presumably because of the presence of other tet genes participating in OXT resistance. However, this study did not detect these genes. VernerJeffreys et al. (2019) reported that most the isolates of Aeromonas spp. resistant to tetracyclines and had tetA, tetD or tetE genes. De Silva et al. (2020) reported that half $(50 \%)$ of the 32 isolates of Aeromonas spp. tested were proven to be resistant to tetracyclines and OXTs, but tetE gene was detected in only two isolates and tetA gene was detected in only one isolate. Fauzi et al. (2021) reported that isolates of Aeromonas spp. that were resistant to kanamycin (the aminoglycoside group) were detected to have $\operatorname{str} A-s t r B$ gene.

Vega-Sanchez et al. (2014) reported that A. hydrophila isolated from infected and healthy rainbow trout $(O$. mykiss) in Mexico, is $100 \%$ resistant to AMP. A. hydrophila isolated from clinical cases (43 isolates) of several aquatic animals, including ornamental goldfish (Carassius auratus), turtles (Amyda cartilaginea), freshwater shrimp (Macrobrachium rosenbergii), goldfish (Cyprinus carpio L.), Chinese freshwater fish (Megalobrama amblvcephaia), Chinese shrimp (Penaeus chinensis), clams (Mytilus edulis), silver goldfish (Hypophthalmichthys molitrix), grass carp (Ctenopharyngodon idellus), and eel (Monopterus albus), exhibit $100 \%$ resistance to AMP, $90.70 \%$ resistance to ERY, and $2.33 \%$ resistance to ENRO (Guo et al. 2014). The same finding is reported by Stratev et al. (2013), who confirmed that A. hydrophila isolates are resistant to AMP and ERY.

The MICs were used to observe the resistance of Aeromonas spp. to antibiotics (Table 2). Each Aeromonas spp. strain was resistant to at least one type of antibiotic. $A$. veronii bv. veronii $\mathrm{SC}-03$ and $A$. caviae $\mathrm{MD}-03$ were resistant to four types of antibiotics but had only one of the three genes tested. This finding shows that having a resistance gene confers Aeromonas spp. with not only resistance but also the ability to adapt and respond to antibiotics.

Table 3 shows that eight isolates (80\%) of Aeromonas spp. were resistant to AMP, seven isolates (70\%) were resistant to ERY, four isolates (40\%) were resistant to OXT, three isolates $(30 \%)$ were resistant to CHL, and one isolate $(10 \%)$ was resistant to KAN. All of the Aeromonas spp. were sensitive to ENRO. OXT, AMP, ENRO, CHL, and ERY have a broad spectrum of activity against grampositive and negative bacteria, although ERY is only partially active against gram-negative bacteria. KAN has a spectrum of gram-negative activity (Soares et al. 2012; Eyler and Shvets 2019). 
Table 2. Resistance of Aeromonas spp. based on the MICs of antibiotics

\begin{tabular}{|c|c|c|c|c|c|c|}
\hline \multirow{2}{*}{ Isolates } & \multicolumn{6}{|c|}{ Types of antibiotics } \\
\hline & OXT $(\mu \mathrm{g} / \mathrm{mL})$ & KAN $(\mu \mathrm{g} / \mathrm{mL})$ & AMP $(\mu \mathrm{g} / \mathbf{m L})$ & ENRO $(\mu \mathrm{g} / \mathrm{mL})$ & ERY $(\mu \mathrm{g} / \mathrm{mL})$ & CHL $(\mu \mathrm{g} / \mathrm{mL})$ \\
\hline SB-01 & 10 & 5 & 10 & 0.2 & $\mathrm{R}$ & 5 \\
\hline SC-03 & $\mathrm{R}$ & 2.5 & $\mathrm{R}$ & 0.05 & $\mathrm{R}$ & $\mathrm{R}$ \\
\hline MS-03 & 2.5 & $\mathrm{R}$ & $\mathrm{R}$ & 1.875 & $\mathrm{R}$ & 7.5 \\
\hline $\mathrm{R}$ & - & 7.5 & $\mathrm{R}$ & 0.1 & 3.75 & 2.5 \\
\hline KO-01 & 1.25 & 2.5 & $\mathrm{R}$ & 0.313 & $\mathrm{R}$ & $\mathrm{R}$ \\
\hline MD-03 & $\mathrm{R}$ & 2.5 & $\mathrm{R}$ & 0.05 & $\mathrm{R}$ & $\mathrm{R}$ \\
\hline DW-04 & 10 & 0.625 & 0.2 & 0.625 & $\mathrm{R}$ & 1.875 \\
\hline BCp-01-2 & 10 & 6.25 & $\mathrm{R}$ & 0.013 & $\mathrm{R}$ & 1.875 \\
\hline ВCp-02-1 & 5 & 5 & $\mathrm{R}$ & 0.025 & 0.625 & 0.313 \\
\hline BCp-02-2 & $\mathrm{R}$ & 2.5 & $\mathrm{R}$ & 0.2 & 3.75 & 1.25 \\
\hline
\end{tabular}

Note: R: resistant

Table 3. Antibiogram profiles of antibiotics tested on Aeromonas spp. based on MICs

\begin{tabular}{lcclc}
\hline \multicolumn{1}{c}{ Antibiotics } & $\begin{array}{c}\text { Number of resistant isolates } \\
(\mathbf{n = 1 0})\end{array}$ & $\boldsymbol{\%}$ & \multicolumn{1}{c}{ Activity spectrum } & References \\
\hline OXT & 4 & 40 & Gram-positive and negative & Soares et al. (2012); \\
KAN & 1 & 10 & Gram-negative & Eyler and Shvets (2019) \\
AMP & 8 & 80 & Gram-positive and negative & \\
ENRO & 0 & 0 & Gram-positive and negative & \\
ERY & 7 & 70 & Gram-positive and negative & \\
CHL & 3 & 30 & Gram-positive and negative & \\
\hline
\end{tabular}

According to the antibiogram profiles result, Aeromonas spp. were the most resistant to AMP (80\%). All Aeromonas spp. isolated from sediments, bivalves, sea cucumbers, and seawater (53 isolates) showed resistance $(100 \%)$ to AMP and penicillin (Odeyemi and Ahmad 2017). Igbinosa and Okoh (2012), who studied 24 isolates of Aeromonas spp. from wastewater treatment plants in Alice and Fort Beaufort, Eastern Cape Province, South Africa, indicated similar findings. These results reveal that all Aeromonas spp. isolates are resistant (100\%) to AMP and penicillin. As many as 61 isolates from A. hydrophila, $A$. veronii bv. veronii, and $A$. veronii bv. sobria were proven to be resistant $(100 \%)$ to AMP and penicillin (Simon et al. 2016). Approximately 50 Aeromonas spp. isolates from various livestock products showed $100 \%$ resistance to AMP (Didugu et al. 2016). This resistance to AMP is believed to be due to the frequent use of the antibiotic to treat Aeromonas spp., thus allowing the latter to adapt to this group of antibiotics despite AMP having a wide spectrum of activity against gram-positive and negative bacteria. Aeromonas spp. may produce the enzyme beta-lactamase, which can damage the structure of beta-lactam. The beta-lactam structure of the penicillin group, including AMP, inhibits bacterial cell wall synthesis (Lakshmi et al. 2014).

Aeromonas spp. showed resistance to ERY (70\%). Aeromonas spp. from a wastewater treatment plant in Alice, Eastern Cape Province, South Africa, are susceptible to ERY (66.7\%) (Igbinosa and Okoh 2012). The results of Simon et al. (2016) indicated that Aeromonas spp. are insensitive to ERY by $39.97 \%$. The results of Olaniran et al. (2015) indicated that Aeromonas sp. are 58\% insensitive to ERY, while Stratev et al. (2013) reported that $A$. hydrophila is $100 \%$ resistant to ERY. Aeromonas spp. maybe resistant to ERY because the latter is more effective against gram-positive than gram-negative bacteria.

Aeromonas spp. exhibited resistant to OXT (40\%). A study by Odeyemi and Ahmad (2017) showed that Aeromonas spp. are unaffected to OXT by $24.5 \%$. Aeromonas spp. from a wastewater treatment plant in Fort Beaufort, Eastern Cape Province, South Africa, are resistant to tetracyclines $(77.8 \%$ ) (Igbinosa and Okoh 2012). Zhou et al. (2019) demonstrated that Aeromonas spp. isolated from extra-intestinal and intestinal infections are $18.3 \%$ resistant to tetracycline. Previous studies also reported that Aeromonas spp. isolated from shrimp, fish and turtle are $33.3 \%, 14.7 \%$ and $50 \%$ resistant to tetracycline, respectively (Deng et al. 2014).

Aeromonas spp. showed resistance to $\mathrm{CHL}$ (30\%). Odeyemi and Ahmad (2017) showed that Aeromonas spp. are insensitive to CHL by $20.8 \%$. Zhou et al. (2019) studied Aeromonas spp. isolated from extra-intestinal and intestinal infections found that bacteria are resistant to $\mathrm{CHL}$ by $8.7 \%$. Aeromonas spp. detected from a wastewater treatment plant in Fort Beaufort, Eastern Cape Province, South Africa, are susceptible to CHL by $61.1 \%$ while those isolated from a wastewater treatment plant in Alice are susceptible to CHL by $83.3 \%$ (Igbinosa and Okoh 2012).

Only one $(10 \%)$ of the 10 tested isolates, namely, $A$. dhakensis MS-03, was resistant to KAN. Odeyemi and Ahmad (2017) showed that Aeromonas spp. are resistant to KAN by $5.7 \%$. Didugu et al. (2016) found contradictory results and revealed that, among 50 isolates of Aeromonas spp. isolated from livestock products, none were resistant to KAN, but sensitie to KAN by $94 \%$ and intermediate to KAN by $6 \%$. 
Table 4. Potential development of Aeromonas spp. resistance based on antibiotic MBCs

\begin{tabular}{lcccc}
\hline Antibiotics & MIC $(\boldsymbol{\mu g} / \mathbf{m L})$ & MBC & Resistance & Antibiotic properties \\
\hline OXT & 1.250 & $>6 \times \mathrm{MIC}$ & $\mathrm{R}$ & Bacteriostatic \\
KAN & 0.625 & $6 \times \mathrm{MIC}$ & $\mathrm{S}$ & Bactericidal \\
AMP & 0.200 & $>6 \times \mathrm{MIC}$ & $\mathrm{R}$ & Bacteriostatic \\
ENRO & 0.013 & $6 \times \mathrm{MIC}$ & $\mathrm{S}$ & Bactericidal \\
ERY & 0.625 & $>6 \times \mathrm{MIC}$ & $\mathrm{R}$ & Bacteriostatic \\
CHL & 0.313 & $4 \times \mathrm{MIC}$ & $\mathrm{S}$ & Bactericidal \\
\hline
\end{tabular}

Note: S: sensitive, R: resistant

Aeromonas spp. were not found to be resistant to ENRO. Didugu et al. (2016) obtained similar findings and revealed that, among 50 Aeromonas spp. isolates obtained from livestock products, none are found resistant to ENRO. The results of a study on 43 A. hydrophila isolates isolated from clinical cases showed that only $2.23 \%$ of the isolates were resistant to ENRO (Guo et al. 2014). Differences in resistance or sensitivity may be attributed to variations in isolate sources, frequency, and types of antimicrobial agents used to treat various infections in different geographic areas (Nagar et al. 2011).

\section{Development of resistance by Aeromonas spp. based on the MBCs of antibiotics}

Six types of antibiotics were tested for resistance development based on the MBC value. The MBCs used were based on the MICs. Table 4 shows that OXT, AMP, and ERY were bacteriostatic. The three other antibiotics, namely, CHL at a concentration of $4 \times \mathrm{MIC}, \mathrm{KAN}$ at a concentration of $6 \times \mathrm{MIC}$, and ENRO at a concentration of $6 \times \mathrm{MIC}$, were bactericidal. These results are in accordance with the antibiogram profiles of the antibiotics (Table 3), consisting of three antibiotics with the smallest number of resistant isolates, including bactericides on the MBC results. Previous research tested the effectiveness of MC21B (produced from the marine bacteria Pseudoalteromonas phenolica O-BC30T) against methicillin-resistant Staphylococcus aureus, and results showed that MC21-B is an effective bactericidal at a concentration of $4 \times \mathrm{MIC}$ (Isnansetyo and Kamei 2009). Other studies tested ketapang leaf extract against $A$. salmonicida, and results indicated that the MIC and MBC of the extract are 50 and $100 \mathrm{mg} / \mathrm{mL}$, respectively; in other words, the $\mathrm{MBC}$ of the extract is $2 \times$ MIC (Sumino et al. 2013).

Although OXT, AMP, and ERY were bacteriostatic, they have a wide spectrum of activity against Grampositive and negative bacteria (Tables 3 and 4). This finding is in accordance with their classification based on their working power, as described in Permenkes No. 2406 of 2011; in particular, OXT and ERY are described as bacteriostatic agents (Kementrian Kesehatan RI 2011). However, in contrast to the results of this study, AMP is classified as bactericidal (Kementrian Kesehatan RI 2011; Tjay and Rahardja 2015). KAN is a bactericidal agent with a spectrum of activity against Gram-negative bacteria (Kementrian Kesehatan RI 2011). ENRO is a bactericidal agent with a wide spectrum of activity against Grampositive and negative bacteria; the antibiotic contains a quinolone group, which has bactericidal properties (Tjay and Rahardja 2015). CHL is another bactericidal agent with a wide spectrum of activity against gram-positive and negative bacteria, but it is not accordance with the classification of bacterial activity, in which CHL is bacteriostatic (Kementrian Kesehatan RI 2011; Tjay and Rahardja 2015). This finding confirms that KAN, ENRO, and CHL could effectively treat fish attacked by Aeromonas spp. Since Aeromonas spp. are Gram-negative bacteria, the use of KAN in this study is appropriate, as this antibiotic focuses on Gram-negative bacteria. Likewise, the use of ENRO and CHL, which are bactericidal and show a broad spectrum of activity, is quite effective for Aeromonas spp. KAN irreversibly binds to the prokaryotic ribosomes of bacteria to inhibit protein synthesis, thereby inhibiting bacterial growth (Neu and Gootz 2001). CHL can inhibit protein synthesis, attach to the $50 \mathrm{~S}$ subunit of ribosome, and interfere with the binding of new amino acids to the peptide chain being formed. CHL mainly inhibits peptidyl transferase (Neu and Gootz 2001). ENRO belongs to the fluoroquinolone class of antibiotics that could inhibit DNA gyrase (topoisomerase II) and topoisomerase IV (topo IV), which are required by bacteria to perform DNA replication. This inhibition produces a cytotoxic effect on the target cells (Babaahmady and Khosravi 2011). Study on resistance genes, susceptibility to antibiotics, and development of resistance to Aeromonas spp. not yet reported in Indonesia. The findings in this study may provide important information about the resistance characteristics of Aeromonas spp. isolated from walking catfish (Clarias sp.) obtained from a cultivation pond in Java Island, Indonesia.

\section{ACKNOWLEDGEMENTS}

This study was funded by Lembaga Pengelola Dana Pendidikan, the Ministry of Finance (No. PRJ4761/LPDP.3/2016). We also thank the Ministry of Research, Technology, and Higher Education, the Republic of Indonesia, for financing this research through the PDD program (No. 2890/UN1.DITLIT/DIT-LIT/LT/2019).

\section{REFERENCES}

Ambadiang MMM, Atontsa BCK, Tankeo SB, Nayim P, Wamba BEN, Bitchagno GTM, Mpetga JDS, Penlap VB, Kuete V. 2020. Bark 
extract of Cassia sieberiana DC. (Caesalpiniaceae) displayed good antibacterial activity against MDR gram-negative phenotypes in the presence of phenylalanine-arginine $\beta$-naphthylamide. BMC Compl Med Ther 20: 342. DOI: 10.1186/s12906-020-03148-3

Angka SL. 2001. Characterization and pathology studies of Aeromonas hydrophila on African catfish (Clarias gariepinus). Papers Philosophy of Science. Program Pascasarjana, Insitut Pertanian Bogor. [Indonesian]

Aravena-Román M, Beaz-Hidalgo R, Inglis TJJ, Riley TV, MartínezMurcia AJ, Chang BJ, Figueras MJ. 2013. Aeromonas australiensi sp. nov., isolated from irrigation water. Intl J Syst Evol Microbiol 63 : 2270-2276. DOI: $10.1099 /$ ijs.0.040162-0.

Babaahmady E, Khosravi A. 2011. Toxicology of baytril (enrofloxacin). Afr J Pharm Pharmacol 5 (18): 2042-2045. DOI: 10.5897/AJPP11.644.

Dahanayake PS, Hossain S, Wickramanayake MVKS, Heo GJ. 2019. Antibiotic and heavy metal resistance genes in Aeromonas spp. isolated from marketed Manila Clam (Ruditapes philippinarum) in Korea. J Appl Microbiol 127 (3): 941-952. DOI: 10.1111/jam.14355.

De Silva BCJ, Hossain S, Dahanayake PS, Heo GJ. 2018. Frozen whiteleg shrimp (Litopenaeus vannamei) in Korean markets as a source of Aeromonas spp. harboring antibiotic and heavy metal resistance genes. Microb Drug Resist 24 (10): 1587-1598. DOI: 10.1089/mdr.2018.0035.

De Silva BCJ, Hossain S, Dahanayake PS, Lee D, Wickramanayake MVKS, Heo G. 2020. Multi-drug resistant mesophilic aeromonads isolated from marketed scallops (Patinopecten yessoensis) harboring resistance genes. Fish Aquat Life 28 (1): 1-10. DOI: 10.2478/aopf2020-0001.

Deng YT, Wu YL, Tan AP, Huang YP, Jiang L, Xue HJ, Wang WL, Luo L, Zhao F. 2014. Analysis of antimicrobial resistance genes in Aeromonas spp. isolated from cultured freshwater animals in China. Microb Drug Resist 20 (4): 350-356. DOI: 10.1089/mdr.2013.0068.

Dias MKR, Sampaio LS, Proietti-Junior AA, Yoshioka ETO, Rodrigues DP, Rodriguez AFR, Ribeiro RA, Faria FS, Ozório ROA, TavaresDias M. 2016. Lethal dose and clinical signs of Aeromonas hydrophila in Arapaima gigas (Arapaimidae), the giant fish from Amazon Vet Microbiol 188: 12-15. DOI: 10.1016/j.vetmic.2016.04.001

Didugu H, Krishnaiah N, Rao MT, Ramanipushpa RN. 2016. Antibiogram of Aeromonas species isolated from livestock products. Intl J Sci Environ 5 (2): 475-478.

Eid HM, Soliman ZI, Hanafy AT. 2019. Antibacterial resistance of Aeromonas species isolated from fish and water of Manzala Lake. Suez Canal Vet Med J 24 (2): 217-230. DOI 10.21608/scvmj.2019.69846.

Erdem B, Kariptaş E, Çil E, Işik K. 2011. Biochemical identification and numerical taxonomy of Aeromonas spp. isolated from food samples in Turkey. Turk J Biol 35: 463-472. DOI: 10.3906/biy-0904-11.

Eyler RF, Shvets K. 2019. Clinical pharmacology of antibiotics. Clin J Am Soc Nephrol 14 (7): 1080-1090. DOI: 10.2215/CJN.08140718.

Fauzi NNFNM, Hamdan RH, Mohamed M, Ismail A, Zin AAM, Mohamad NFA. 2021. Prevalence, antibiotic susceptibility, and presence of drug resistance genes in Aeromonas spp. isolated from freshwater fish in Kelantan and Terengganu states, Malaysia. Vet World 14: 2064-2072. DOI:10.14202/vetworld.2021.2064-2072.

Guo P, Wang N, Liu Y, Lu C. 2014. Antimicrobial susceptibility and characterization of outer membrane proteins of Aeromonas hydrophila isolated in China. J Integr Agric 13 (4): 911-917. DOI: 10.1016/S2095-3119(13)60312-3.

Guo SL, Yang QH, Feng JJ, Duan LH, Zhao JP. 2016. Phylogenetic analysis of the pathogenic genus Aeromonas spp. isolated diseased eels in China. Microb Pathol 101: 12-23. DOI: 10.1016/j.micpath.2016.10.016.

Harnisz M, Korzeniewska E. 2018. The prevalence of multidrug-resistant Aeromonas spp. in the municipal wastewater system and their dissemination in the environment. Sci Total Environ 626: 377-383. DOI: 10.1016/j.scitotenv.2018.01.100.

Hassan MA, Noureldin EA, Mahmoud MA, Fita NA. 2017. Molecular identification and epizootiology of Aeromonas veronii infection among farmed Oreochromis niloticus in Eastern Province, KSA. Egypt J Aquat Res 43 (2): 161-167. DOI: 10.1016/j.ejar.2017.06.001.

Igbinosa IH, Okoh AI. 2012. Antibiotic susceptibility profile of Aeromonas species isolated from wastewater treatment plant. The Sci World J 2012: 764563. DOI: 10.1100/2012/764563.
Isnansetyo A, Kamei Y. 2009. Anti-methicillin-resistant Staphylococcus aureus (MRSA) activity of MC21-B, an antibacterial compound produced by the marine bacterium Pseudoalteromonas phenolica O$\mathrm{BC} 30^{\mathrm{T}}$. Intl J Antimicrob Agents 34 (2): 131-135. DOI: 10.1016/j.ijantimicag.2009.02.009.

Kementerian Kesehatan RI. 2011. General Guidelines for Use of Antibiotics. Jakarta: Departmen Kesehatan RI. 63 hal. [Indonesian].

Kepmen KP. 2014. Decree of the Minister of Marine Affairs and Fisheries RI No.52/KEPMEN-KP/2014 Concerning the Classification of Fish Medicines. Minister of Marine Affairs and Fisheries of the Republic of Indonesia, Jakarta. [Indonesian].

Lakshmi R, Nusrin KS, Georgy SA, Sreelakshmi KS. 2014. Role of beta lactamases in antibiotic resistance: A review. Intl Res J Pharm 5 (2): 37-40. DOI: 10.7897/2230-8407.050207.

Martínez-Murcia A, Beaz-Hidalgo R, Navarro A, Carvalho MJ, AravenaRomán M, Correia A, Figueras MJ, Saavedra MJ. 2016. Aeromonas lusitana sp. nov., isolated from untreated water and vegetables. Curr Microbiol 72: 795-803. DOI: 10.1007/s00284-016-0997-9.

Mulia DS, Isnansetyo A, Pratiwi R, Asmara W. 2020. Molecular characterizations of Aeromonas caviae isolated from catfish (Clarias $\begin{array}{lllll}\text { sp.). } & \text { AACL } & \text { Bioflux } & 13 & \text { (5): }\end{array}$ https://www.cabdirect.org/cabdirect/abstract/20203600153

Nagar V, Shashidhar R, Bandekar JR. 2011. Prevalence, characterization, and antimicrobial resistance of Aeromonas strains from various retail food products in Mumbai, India. J Food Sci 76 (7): M486-M492. DOI: $10.1111 /$ j.1750-3841.2011.02303.x.

Nawaz M, Khan SA, Tran Q, Sung K, Khan A.A, Adamu I, Steele RS. 2012 Isolation and characterization of multidrug-resistant Klebsiella spp. isolated from shrimp imported from Thailand. Int J Food Microbiol 155 (3): 179-184. DOI: 10.1016/j.ijfoodmicro.2012.02.002.

NCCLS. 1994. Performance standards for antimicrobial disk and dilution susceptibility tests for bacterial isolated from animals: Proposed standard. NCCLS Document m31-P: 1-29. 14(20).

Neu HC, Gootz TD. 2001. Antimicrobial chemotherapy. In: Baron S (eds). Medical Microbiology. 5th edition. The University of Texas Medical Branch, Galtestone.

Nguyen F, Starosta AL, Arenz S, Sohmen D, Dönhöfer A, Wilson DN. 2014. Tetracycline antibiotics and resistance mechanisms. Biol Chem 395 (5): 559-575. DOI:10.1515/hsz-2013-0292.

Odeyemi OA, Ahmad A. 2017. Antibiotic resistance profiling and phenotyping of Aeromonas species isolated from aquatic sources. Saudi J Biol Sci 24 (1): 65-70. DOI: 10.1016/j.sjbs.2015.09.016.

Olaniran AO, Nzimande SB T, Mkize NG. 2015. Antimicrobial resistance and virulence signatures of Listeria and Aeromonas species recovered from treated wastewater effluent and receiving surface water in Durban, South Africa. BMC Microbiol 15: 234. DOI: 10.1186/s12866-015-0570-x.

Parker JL, Shaw JG. 2011. Aeromonas spp. clinical microbiology and disease. J Infect 62 (2): 109-118. DOI: 10.1016/j.jinf.2010.12.003.

Percival SL, Williams DW. 2014. Aeromonas. In: Percival SL, Williams DW, Gray FN, Yates MV, Chalmers RM. (eds). Microbiology of waterborne diseases: Microbiological aspects and risks. 2nd edition. Elsevier, London. DOI: 10.1016/B978-0-12-415846-7.00003-2

Sellegounder D, Gupta YR, Murugananthkumar R, Senthilkumaran B. 2018. Enterotoxic effects of Aeromonas hydrophila infection in the catfish, Clarias gariepinus: Biochemical, histological and proteome analyses. Vet Immunol Immunopathol 204: 1-10. DOI: 10.1016/j.vetimm.2018.08.008.

Shakil S, Khan R, Zarrilli R, Khan AU. 2008. Aminoglycosides versus bacteria-a description of the action, resistance mechanism, and nosocomial battleground. J Biomed Sci 15 (1): 5-14.

Simon SS, Lalitha KV, Joseph TC. 2016. Virulence properties of Aeromonas spp. from modified-atmosphere- and vacuum-packed milk fish (Chanos chanos Forsskal, 1775). Ann Microbiol 66 (3): 11091115. DOI: $10.1007 / \mathrm{s} 13213-016-1193-7$.

Soares GMS, Figueiredo LC, Faveri M, Cortelli SC, Duarte PM, Feres M. 2012. Mechanisms of action of systemic antibiotics used in periodontal treatment and mechanisms of bacterial resistance to these drugs. J Appl Oral Sci 20 (3): 295-309. DOI: 10.1590/s167877572012000300002

Stoll C, Sidhu JPS, Tiehm A, Toze S. 2012. Prevalence of clinically relevant antibiotic resistance genes in surface water samples collected from Germany and Australia. Environ Sci Technol 46 (17): 97169726. DOI: $10.1021 / \mathrm{es} 302020$ s 
Stratev D, Vashin I, Daskalov H. 2013. Antimicrobial resistance of $\beta$ haemolytic Aeromonas hydrophila isolated from rainbow trouts (Oncorhynchus mykiss). Boll J Vet Med 16 (4): 289-296.

Stratev D, Odeyemi OA. 2016. Antimicrobial resistance of Aeromonas hydrophila isolated from different food sources: A mini-review. J Infect Public Health 9 (5): 535-544. DOI: 10.1016/j.jiph.2015.10.006.

Sumino SA, Wardiyanto. 2013. The effectiveness of ketapang (Terminalia cattapa L.) leave extract for the treatment of Aeromonas salmonicida infection in catfish (Pangasioniodon hypophthalmus). Jurnal Sain Veteriner 31 (1): 79-88. [Indonesian].

Tipmongkolsilp N, del Castillo CS, Hikima J, Jung T, Kondo H, Hirono I, Aoki T. 2012. Multiple drug-resistant strains of Aeromonas hydrophila isolated from tilapia farms in Thailand. Fish Pathol 47 (2): 56-63.

Tjay TH, Rahardja K. 2015. Important Medicines: Benefits, Uses and Side Effects. 7th edition. Elex Media Komputindo, Jakarta. [Indonesian].

Varela AR, Nunes OC, Manaia CM. 2016. Quinolone resistant Aeromonas spp. as carriers and potential tracers of acquired antibiotic resistance in hospital and municipal wastewater. Sci Total Environ 542: 665671. DOI: 10.1016/j.scitotenv.2015.10.124.

Vega-Sánchez V, Acosta-Dibarrat J, Vega-Castillo F, Castro-Escarpulli G, Aguilera-Arreola MG, Soriano-Vargas E. 2014. Phenotypical characteristics, genetic identification, and antimicrobial sensitivity of Aeromonas species isolated from farmed rainbow trout (Onchorynchus mykiss) in Mexico. Acta Trop 130: 76-79. DOI 10.1016/j.actatropica.2013.10.021
Verner-Jeffreys DW, Welch TJ, Schwarz T, Pond MJ, Woodward MJ, Haig SJ, Rimmer GSE, Roberts E, Morrison V, Baker-Austin C. 2009. High prevalence of multidrug-tolerant bacteria and associated antimicrobial resistance genes isolated from ornamental fish and their carriage water. PLoS One 4 (12): e8388. DOI: 10.1371/journal.pone.0008388.

Wang L, Wei Y, Yuan G, Dai M, Chen X. 2012. Molecular characterization and virulence genes of Aeromonas hydrophila isolated from the Chinese giant salamander (Andrias davidianus). $\begin{array}{lllll}\text { Asian Herpetol Res } 3 \text { (4): 303-309. DOI: } & \end{array}$ 10.3724/SP.J.1245.2012.00303

Wimalasena SHMP, de Silva BCJ, Hossain S, Pathirana HNKS, Heo GJ. 2017. Prevalence and characterisation of quinolone resistance genes in Aeromonas spp. isolated from pet turtles in South Korea. J Glob Antimicrob Resist 11: 34-38. DOI: 10.1016/j.jgar.2017.06.001.

Yano Y, Hamano K, Tsutsui I, Aue-Umneoy D, Ban M, Satomi M. 2015. Occurrence, molecular characterization, and antimicrobial susceptibility of Aeromonas spp. in marine species of shrimps cultured at inland low salinity ponds. Food Microbiol 47: 21-27. DOI: 10.1016/j.fm.2014.11.003.

Zhou Y, Yu L, Nan Z, Zhang P, Kan B, Yan D, Su J. 2019. Taxonomy, virulence genes and antimicrobial resistance of Aeromonas isolated from extra-intestinal and intestinal infections. BMC Infect Dis 19: 158. DOI: $10.1186 / \mathrm{s} 12879-019-3766-0$. 